\title{
KUALITAS MINUMAN SARI BIJI NANGKA (Artocarpus heterophyllus)DENGAN PENAMBAHAN JAHE MERAH(Zingiber officinale varrubrum rhizoma)
}

\section{QUALITY OF DRINKING JACKFRUIT JUICE(Artocarpus heterophyllus)WITH ADDITION OF RED GINGER(Zingiber officinale varrubrum rhizoma)}

\author{
Syahri Fadhila Al-Farid'), Jamaluddin2), Andi Sukainah'3) \\ 1) Alumni Program Studi Pendidikan Teknologi Pertanian FT UNM \\ 2) dan 3) Dosen PTP FT UNM \\ Syahrifadhila1@gmail.com
}

\begin{abstract}
ABSTRAK
Penelitian ini bertujuan untuk mengetahui kualitas minuman sari biji nangka dengan penambahan jahe merah dan untuk mengetahui tingkat penerimaan panelis terhadap minuman sari biji nangka. Parameter yang diamati meliputi kadar air, kandungan protein, kandungan karbohidrat dan organoleptik termasuk warna, rasa, aroma dan tekstur. Penelitian ini menggunakan Rancangan Acak Lengkap (RAL) yang terdiri dari satu faktor, yaitu konsentrasi sari jahe merah dengan empat perlakuan, yaitu: $0 \%, 6 \%, 12 \%, 18 \%$, masing-masing diulang tiga kali. Hasil penelitian menunjukkan bahwa sari biji nangka minum dengan penambahan sari jahe merah $18 \%$ merupakan perlakuan terbaik dari hasil uji organoleptik. Hasil uji proksimat menunjukkan bahwa perlakuan terbaik adalah kadar air 3,13\% pada perlakuan jahe $12 \%, 2,17$ protein pada perlakuan sari jahe merah $18 \%$ dan 95,61 karbohidrat pada perlakuan jahe merah 18\%.
\end{abstract}

Kata kunci: Sari Buah Nangka, Jahe Merah, Organoleptik, Uji Proksimat.

\begin{abstract}
This study aims to determine the quality of jackfruit seed juice drinks with the addition of red ginger and to determine the level of acceptance of panelists on jackfruit seed juice drinks. Parameters observed included water content, protein content, carbohydrate content and organoleptic including color, taste, aroma and texture. This study used a Completely Randomized Design (CRD) consisting of one factor, namely the concentration of red ginger juice with four treatments, namely: $\%, 6 \%, 12 \%, 18 \%$, each repeated three times. The results showed that jackfruit seed juice drink with the addition of $18 \%$ red ginger was the best treatment from the results of organoleptic tests. The proximate test results showed that the best treatment was $3.13 \%$ water content in $12 \%$ ginger treatment, $2.17 \%$ protein in $18 \%$ red ginger treatment and 95.61 carbohydrate in $18 \%$ red ginger treatment.
\end{abstract}

Keywords: Jackfruit Seed Sari, Red Ginger Organoleptic, Proximate Test

\section{PENDAHULUAN}

Tanaman nangka (Artocarpus heterophyllus lamk) adalah jenis tanaman tropis yang banyak tumbuh di Indonesia.Tanaman nangka (Artocarpus heterophyllus lamk) dapat ditanam dengan ketinggian kurang dari $1.000 \mathrm{~m}$ di atas permukaan laut, tanaman ini berasal dari India Selatan.Pemanfaatan nangka masih terbatas sehingga masyarakat hanya mengkonsumsi daging buah segarnya saja yaitu dami nangka.Dami nangka biasanya dibuat manisan kering dan campuran sayur 
gudangan. Nangka muda dibuat gudeg dan campuran sayur seperti pecel dan lodeh; nangka matang dibuat sirup, dodol, keripik, kolak, puding atau dimakan dalam keadaan segar. Biji nangka yang sangat melimpah belum banyak dimanfaatkan atau dibuang begitu saja tanpa ada pengolahan lebih lanjut.Biji nangka mempunyai harga relatif murah, umumnya biji nangka hanya dimanfaatkan dalam bentuk biji nangka bakar, rebus, dan goreng (Widyastuti, 1993).

Biji nangka ialah biji yang berasal dari buah nangka berbentuk bulat lonjong, permukaan kulit buah kasar dan berduri. Biji nangka berbentuk bulat sampai lonjong, berukuran kecil, kurang lebih ukuran panjang biji nangka sekitar 3,5-4,5 cm dengan berat berkisar 3 hingga $9 \mathrm{~g}$. Biji nangka berkeping dua, jumlah rata-rata biji setiap buah nangka adalah 30 hingga 50 biji dan rasio berat biji terhadap buah sekitar sepertiga di mana sisanya adalah kulit dan daging buah.

Biji nangka memiliki banyak kandungan yang bermanfaat. Biji nangka memiliki kandungan karbohidrat $(36,7 \mathrm{~g} / 100$ g), protein $(4,2 \mathrm{~g} / 100 \mathrm{~g})$ dan energi (165 $\mathrm{kkal} / 100 \mathrm{~g}$ ), sehingga dapat dimanfaatkan sebagai bahan pangan yang potensial. Jika dibandingkan dengan berbagai jenis tanaman yang umum dipakai sebagai penghasil karbohidrat, maka biji nangka tersebut termasuk memiliki kadar nutrisi yang relatif potensial seperti: Kalori, protein, lemak, karbohidrat, kalsium, zat besi, fosfor dan kadar air.

Potensi biji nangka yang besar belum dieksploitasi secara optimal.Masih rendahnya pemanfaatan biji nangka dalam bidang pangan hanya sebatas sekitar $10 \%$ disebabkan kurangnya minat masyarakat dalam pengolahan biji nangka. Biji nangka mempunyai beberapa keuntungan sebagai bahan baku dalam pembuatan sari biji nangka. Pengolahan biji nangka menjadi produk sari biji nangka antara lain kandungan patinya mencukupi sehingga dapat digunakan sebagai karbohidrat terlarut juga sebagai upaya untuk mengolah biji nangka menjadi produk yang bermanfaat. Upaya yang dilakukan untuk mengolah biji nangka menjadi produk yang bermanfaat sebagai alternatif penambah sumber bahan pangan baru adalah pengolahan biji nangka menjadi minuman instan dalam bentuk bubuk yang mempunyai nilai jual yang tinggi.Karakteristik bubuk dari biji nangka dalam pembuatan minuman instan dimaksudkan untuk memperpanjang umur simpan pada produk, meningkatkan nilai ekonomis serta memudahkan aplikasi produk. Minuman instan bubuk merupakan suatu produk yang proses pengolahannya melalui proses pengkristalan pada bahan baku dan bahan lainnya untuk pembuatan minuman instan.

Pengolahan minuman instan sari biji nangka memerlukan sentuhan bahan tambah untuk menambah cita rasa, memberi aroma, menambah khasiat dari minuman juga sebagai kekhasan minuman inovatif ini. Masyarakat relatif menyukai minuman yang segar dan hangat khusunya bila tiba musim dingin. Salah satu tanaman rempah yang memiliki khasiat dan menyegarkan adalah jahe.

Jahe merupakan tanaman yang mengandung minyak menguap, minyak tak menguap (Non volatile oil) dan pati.Minyak menguap yang biasa disebut minyak atsiri merupakan komponen pemberi bau yang khas, sedangkan minyak yang tak menguap 
biasa disebut oleoresin merupakan komponen pemberi rasa pedas dan pahit (Kusumaningati, 2009).Di antara ketiga jenis jahe, rimpang jahe merah mengandung zat gingerol, oleoresin, dan minyak atsiri yang tinggi, sehingga lebih banyak digunakan (Lentera, 2002).Selain itu, kandungan oleoresin jahe merah juga lebih tinggi dibandingkan jahe lainnya, yaitu 3\% dari bobot kering.

Menurut Widiyanti (2009), jahe banyak digunakan dalam ramuan obat tradisional. Selain itu, rimpang jahe merah dapat digunakan sebagai obat gosok untuk mengobati encok dan sakit kepala. Secara umum, efek farmakologis jahe merah mengandung banyak manfaat seperti melancarkan sirkulasi darah, meningkatkan sistem kekebalan tubuh, antiradang, penambah nafsu makan dan sangat baik dikonsumsi oleh wanita yang sedang dalam menstruasi, untuk mengurangi rasa sakit pada saat haid, sangat berguna untuk memulihkan stamina, meredakan nyeri dan pegal linu, memperkuat daya tahan sperma, melindungi hati, penghangat tubuh, mergenerasi sel-sel kulit tubuh, mencegah penuaan dini, anti rematik, obat pelancar sembelit dan buang air besar yang kurang lancar, mengobati pusing dan amandel serta radang tenggorokan, sakit pinggang dan asma. Berdasarkan khasiat yang dikandung oleh jahe maka sangat sesuai untuk dikombinasikan dengan pengolahan sari biji nangka.Berdasarkan hal tersebut, peneliti bertujuan membuat minuman sari biji nangka dengan penambahan jahe merah.

\section{TUJUAN PENELITIAN}

Penelitian ini bertujuan Untuk mengetahui pengaruh konsentrasi penambahan jahe merah terhadap kandungan gizi minuman sari biji nangka dan untuk mengetahui penerimaan panelis terhadap minuman sari biji nangka dengan konsentrasi penambahan jahe merah.

\section{METODE PENELITIAN}

Penelitian ini termasuk penelitian eksperimen dengan menggunakan Rancangan Acak Lengkap dengan menggunakan empat perlakuan dengan ulangan sebanyak tiga kali, maka jumlah unit percobaan yang akan diperoleh sebanyak 12 unit.

Penelitian ini dilaksanakan di laboratorium Pendidikan Teknologi Pertanian Fakultas Teknik Universitas Negeri Makassar dan di Laboratorium Kimia Fakultas Peternakan Universitas Hasanuddin pada bulan Agustus 2017.

Alat yang digunakan seperti baskom, sendok, pisau, cabinet drayer, stop watch, timbangan, wajan, spatula, talang. Sementara bahan yang digunakan yaitu tomat, kapur sirih, gula pasir, gula merah.

Pelaksanaan penelitian ini dimulai dari pemilihan buah tomat yang masak, segar dan seragam lalu dicuci. Tomat ditimbang sebanyak $1 \mathrm{~kg}$ untuk setiap pengeringan kemudian biji tomat dikeluarkan dan dilakukan perendaman dalam $2 \%$ larutan kapur sirih $\mathrm{Ca}(\mathrm{HO})_{2}$ selama 2 jam. Buah tomat dibilas untuk mengeluarkan sisa kapur sirih dan ditiriskan kemudian disusun dalam wadah ditambahkan gula pasir dan gula merah dengan penambahan $40 \% \mathrm{~b} / \mathrm{b}$. Setelah itu dilakukan proses pemasakan pada tomat diaduk sampai air tomat keluar dan mengental selama \pm 30 menit. Tomat yang telah dimasak kemudian dikeringkan dengan variasi waktu 10, 12 dan 14 jam.Proses pengeringan dilakukan dengan 
menggunakan Cabinet Drayer suhu $60^{\circ} \mathrm{C}$. Manisan tomat dikeluarkan dari mesin pengeringan kemudian dikemas dalam wadah plastik Selanjutnya dilakukan analisis mutu meliputi pengujian kadar air, vitamin $\mathrm{C}$ dan uji organoleptik yaitu warna, aroma, rasa dan tekstur.

\section{HASIL DAN PEMBAHASAN}

\section{Uji Organoleptik}

\section{Warna}

Warna merupakan indikator uji organoleptik yang cukup penting karna warna adalah parameter yang diamati secara langsung melalui indra penglihatan (Ernasari, dkk. 2018).Hasil tingkat kesukaan panelis terhadap warna minuman sari biji nangka dapat dilihat pada Gambar 1.

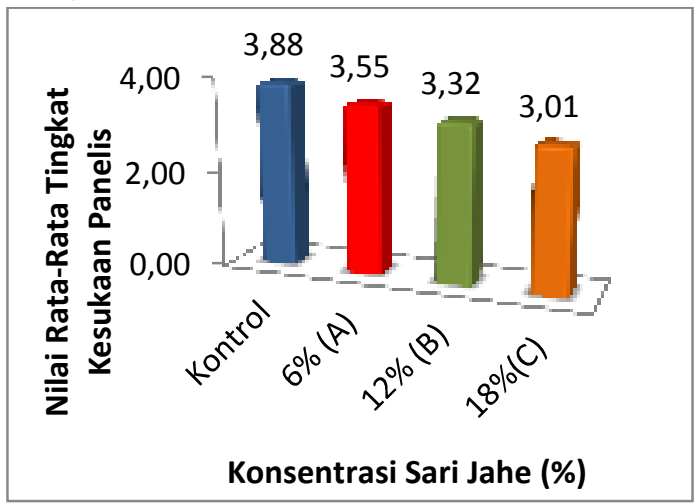

Gambar 1.

Hasil Uji Hedonik Warna Minuman Sari Biji Nangka

Hasil nilai rata-rata menunjukkan bahwa dalam pembuatan minuman sari biji nangka panelis paling menyukai warna minuman sari biji nangka tanpa penambahan jahe merah (kontrol) dengan nilai rata-rata $3,88 \%$, sedangkan hasil terendahterdapat pada penambahan sari jahe $18 \%$ dengan nilai rata-rata 3,01 .Warna yang dihasilkan minuman sari biji nangka tanpa penambahan jahe merah yaitu putih cerah sedangkan warna yang dihasilkan minuman sari biji nangka dengan penambahan jahe merah memberikan warna putih kekuningan.Warna kekuningan tersebut didapatkan dari warna asli jahe yang digunakan yaitu jahe merah dan karena adanya kandungan minyak atsiri dari jahe merah. Sejalan dengan penelitian Fatriani dan Nurul (2007), yang menyatakan bahwa warna dalam pengujian ini dilakukan dengan cara pengujian visual atau kasat mata, dimana dapat langsung dilihat warna minyak atsiri yang dihasilkan yaitu kuning muda hingga kuning kecoklatan. Adanya peningkatan warna kekuningan pada minuman sari biji nangka.

\section{Rasa}

Rasa merupakan rangsangan yang ditimbulkan oleh bahan yang dimakan, terutama dirasakan oleh indera pengecap. Rasa merupakan salah satu faktor yang mempengaruhi penerimaan seseorang terhadap suatu makanan. Rasa secara umum dapat dibedakan menjadi asin, manis, pahit dan asam (Winarno, 2002).Hasil tingkat kesukaan panelis terhadap rasa manisan tomat dapat dilihat pada Gambar 2.

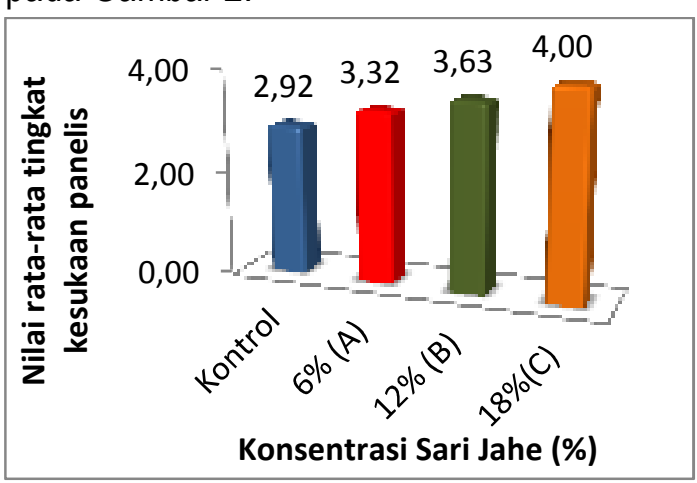

Gambar 2.

Hasil Uji Hedonik Rasa Minuman Sari Biji Nangka

Hasil nilai rata-rata menunjukkan bahwa dalam pembuatan minuman sari biji 
nangka panelis paling menyukai warna minuman sari biji nangka dengan penambahan sari jahe $18 \%$ dengan nilai rata-rata 4,00\%, sedangkan hasil terendah terdapat pada kontrol (tanpa penambahan sari jahe merah) dengan nilai rata-rata yang dihasilkan yaitu $2,92 \%$. Hal ini disebabkan karena minuman sari biji nangka yang disajikan kepada panelis memiliki rasa khas dari jahe merah, di mana jahe merah memiliki kandungan minyak atsiri yang memberikan rasa khas jahe.Jahe merah terdapat kandungan minyak atsiri yang terdiri dari zingiberon, oleoresin, zingiberol yang menimbulkan rasa khas pada jahe merah (Zingiber officinale). Minyak atsiri sangat penting sebagai sumber rasa dan obat (Lata,dkk., 2000). Minyak atsiri digunakan untuk memberi rasa dan aroma makanan, minuman, parfum dan kosmetik (Keita,dkk., 2000).

\section{Aroma}

Aroma merupakan parameter yang berpengaruh terhadap penerimaan produk pada konsumen, dimana aroma pada bahan pangan akan berpengaruh terhadap tingkat kekhasan pada produk pangan (Febriyant, dkk., 2018).Hasil tingkat kesukaan panelis terhadap aroma manisan tomat dapat dilihat pada Gambar 3.

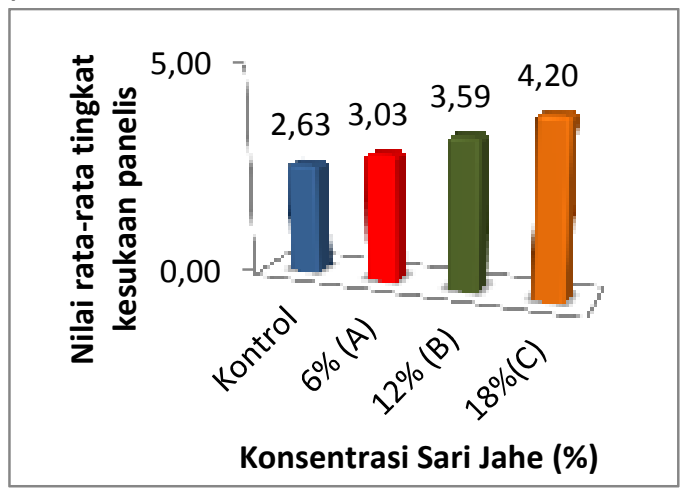

Gambar 3.

Hasil Uji Hedonik Aroma Minuman Sari Biji Nangka
Hasil nilai rata-rata menunjukkan bahwa dalam pembuatan minuman sari biji nangka panelis paling menyukai aroma minuman sari biji nangka dengan penambahan sari jahe $18 \%$ dengan nilai rata-rata $4,20 \%$, sedangkan hasil terendah terdapat pada kontrol dengan nilai rata-rata yang dihasilkan yaitu 2,63\%. Hal ini disebabkan karena minuman sari biji nangka yang disajikan kepada panelis memiliki aroma khas dari jahe merah yang ditambahkan, di mana jahe merah memiliki kandungan minyak atsiri yang menghasilkan aroma khas jahe.Zat volatil dalam jahe bertanggung jawab dalam aroma jahe yang khas (Widiyanti, 2009).Minyak atsiri umumnya berwarna kuning, sedikit kental dan merupakan senyawa yang memberikan aroma khas pada jahe (Soepardie, 2001).

\section{Tekstur}

Uji organoleptik tingkat kesukaan (hedonik) dengan memperhatikan parameter tekstur, pengamatan terhadap tekstur manisan tomat dilakukan dengan cara penentuan tingkat kesukaan tekstur secara sensori. Hasil tingkat kesukaan panelis terhadap tekstur minuman sari biji nangka dapat dilihat pada Gambar 4.

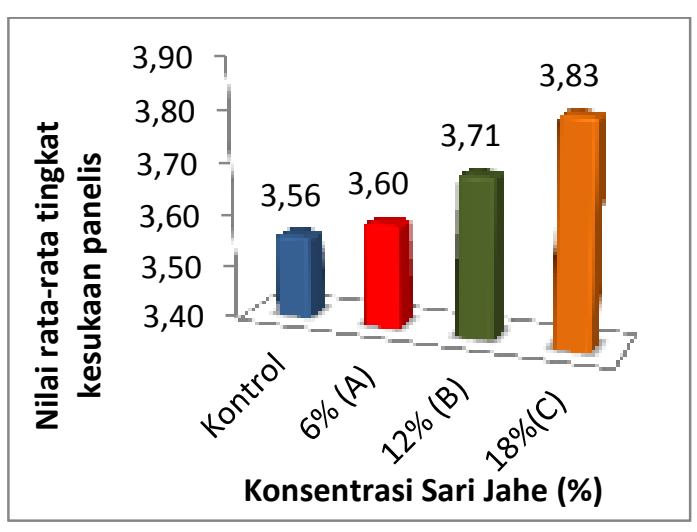

Gambar 4. 
Hasil Uji Hedonik Tekstur Minuman Sari Biji Nangka

Hasil nilai rata-rata menunjukkan bahwa dalam pembuatan minuman sari biji nangka panelis paling menyukai tekstur minuman sari biji nangka dengan penambahan sari jahe $18 \%$ dengan nilai rata-rata-rata $3,83 \%$, sedangkan hasil terendah terdapat pada kontrol dengan nilai rata-rata yang dihasilkan 3,56\%. Hal ini disebabkan karena minuman sari biji nangka yang disajikan kepada panelis memiliki tekstur yang lebih halus, dikarenakan banyak penambahan kensentrasi sari jahe yang di tambahkan sehingga memperlambat proses kristalisasi yang membuat granula gula menurun. Menurut Wahyuni (2005), konsentrasi yang ditambahkan kedalam adonan akan menyebabkan lamanya proses kristalisasi sehingga menyebabkan tekstur lebih halus akibat granula gula menurun.

\section{Uji Proksimat}

\section{Kadar Air}

Kadar air merupakan salah satu karakteristik yang sangat penting pada bahan pangan, karena air dapat mempengaruhi penampakan, tekstur, dan citarasa pada bahan pangan. Makin rendah kadar air, makin lambat petumbuhan mikroorganisme sehingga bahan pangan tersebut dapat bertahan lama. Sebaliknya makin tinggi kadar air makin cepat mikroorganisme berkembang biak, sehingga proses pembusukan akan berlangsung lebih cepat (Winarno, 2002). Analisis kadar air dilakukan untuk mengetahui kandungan kadar air pada minuman sari biji nangka. Hasil analisis kadar airdari berbagai perlakuan dapat dilihat pada Gambar 5.

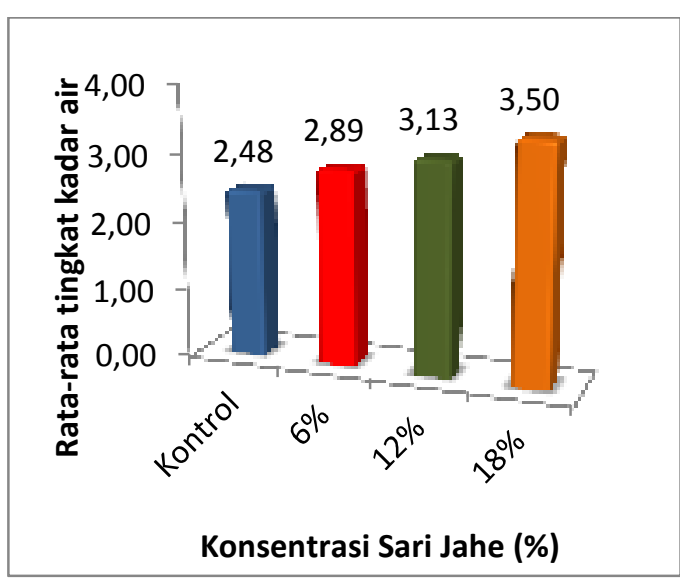

Gambar 5.

Hasil Uji Kadar Air Minuman Sari Biji Nangka

Hasil uji lanjut Duncan menunjukkan perlakuan terbaik terdapat pada perlakuan penambahan jahe merah $12 \%$ dengan hasil 3,13 , sedangkan untuk hasil terendah menunjukkan pada perlakuan kontrol dengan dengan hasil 2,48. Hal ini disebabkan karena kadar air minuman sari biji nangka $12 \%$ memenuhi standar kadar air pada minuman bubuk. Menurut SNI 014320-1996, kadar air pada minuman bubuk adalah 3,0-5,0\%. Serat pangan memiliki daya serap air yang tinggi karena ukuran polimernya besar, strukturnya kompleks dan banyak mengandung gugus hidroksil sehingga mampu menyerap air dalam jumlah besar (Sumardana,dkk.,2017).

\section{Kadar Protein}

Protein merupakan bahan pangan yang penting sebagai penyusun komponenkomponen sel, terutama dalam proses pertumbuhan dan perkembangan makhluk hidup. Analisis kadar protein dilakukan untuk mengetahui kandungan kadar protein pada minuman sari biji nangka. Hasil analisis kadar proteindari berbagai perlakuan dapat dilihat pada Gambar 6 . 


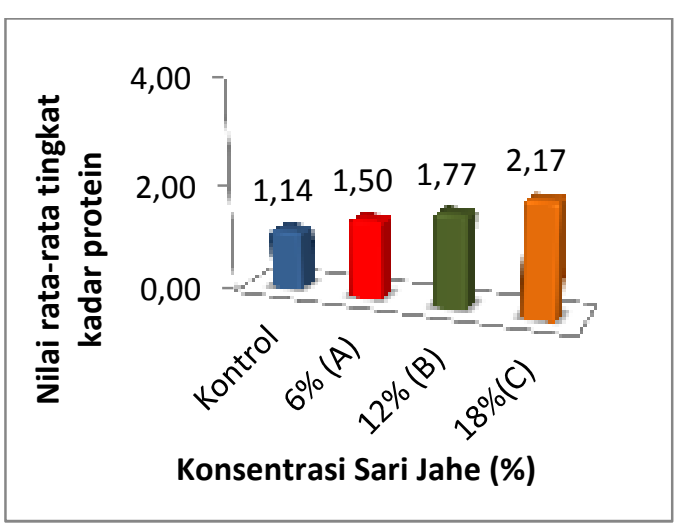

Gambar 6.

Hasil Uji Kadar Protein Minuman Sari Biji Nangka

Hasil uji lanjut Duncan menunjukkan perlakuan terbaik terdapat pada perlakuan penambahan jahe merah $18 \%$ dengan hasil 2,17 , sedangkan untuk hasil terendah menunjukkan pada perlakuan kontrol dengan dengan hasil 1,14. Hal ini disebabkan karena pada jahe merah mengandung protein, sehingga semakin tinggi penambahan jahe merah maka kandungan protein pada minuman sari biji nangka semakin tinggi.Sejalan dengan pendapat Alhim, dkk. (2016), semakin tinggi konsentrasi ekstrak jahe merah maka kadar protein semakin menigkat, karena didalam jahe merah terdapat kandungan protein yang dapat meningkatkan kadar proteinnya. Menurut Widiyanti (2009), pada jahe itu sendiri selain mengandung komponen minyak menguap dan minyak tak menguap, jahe juga mengandung protein sebesar $12,3 \%$, sehingga minuman sari biji nangka yang dilakukan perlakuan penambahan jahe, kadar proteinnya lebih tinggi daripada minuman sari biji nangka yang tidak dilakukan penambahan sari jahe, karena sari biji nangka dengan penambahan sari jahe mendapatkan tambahan protein dari jahe itu sendiri. Namun karena protein merupakan energi yang mudah larut dalam air dan pemasakan dengan suhu tinggi, sehingga kandungan protein pada minuman sari biji nangka yang dihasilkan menurun.Pengolahan bahan pangan sangat mempengaruhi kerusakan yang terjadi pada protein.Semakin tinggi suhu dan semakin lama waktu pengolahan semakin tinggi kerusakan protein yang terjadi pada bahan pangan tersebut.

\section{Karbohidrat}

Karbohidrat merupakan sumber kalori utama hampir seluruh penduduk dunia. Oleh karena fungsinya yang amat penting bagi tubuh, maka diperlukan analisa kadar karbohidrat yang terdapat dalam minuman sari biji nangka. Karbohidrat juga berguna untuk mencegah pemecahan protein yang berlebihan, kehilangan mineral dan membantu metabolisme lemak dan protein (Winarno, 2002). Hasil analisis kadar proteindari berbagai perlakuan dapat dilihat pada Gambar 7.

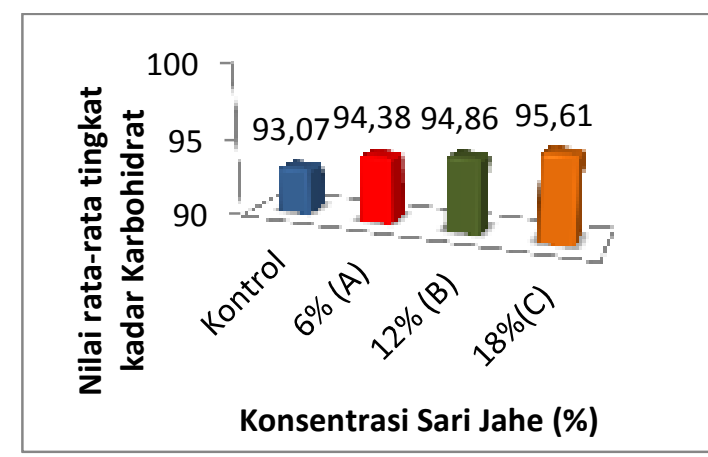

Gambar 7.

Hasil Uji Kadar Karbohidrat Minuman Sari Biji Nangka

Hasil uji lanjut Duncan menunjukkan perlakuan terbaik terdapat pada perlakuan penambahan jahe merah $18 \%$ dengan hasil 95,61, sedangkan untuk hasil terendah menunjukkan pada perlakuan kontrol dengan dengan hasil 93,07. . Hal ini disebabkan karena pada jahe merah 
mengandung karbohidrat yang cukup tinggi, sehingga semakin tinggi penambahan jahe merah maka kandungan karbohidrat pada minuman sari biji nangka semakin tinggi.Sejalan dengan penelitian Sari, dkk.(2016) menyatakan bahwa hasil pengujian menunjukkan semakin banyak jumlah biji nangka yang ditambahkan maka akan semakin tinggi kandungan karbohidrat yang dikandung. Menurut Departemen Kesehatan RI (2000), kandungan karbohidrat pada jahe sebesar $10,1 \mathrm{~g}$ per 100 g. Menurut Sugito dan Ari (2006), kadar karbohidrat dipengaruhi oleh komponen nutrisi lain, semakin rendah komponen nutrisi lain maka kadar karbohidrat akan semakin tinggi. Komponen nutrisi yang mempengaruhi besarnya kandungan karbohidrat diantaranya adalah kandungan protein, lemak, air, dan abu.

\section{KESIMPULAN}

Berdasarkan hasil pembahasan
dalam penelitian ini, maka dapat
disimpulkan bahwa penambahan sari jahe
merah pada pembuatan sari biji nangka
memberikan pengaruh sangat nyata,
dimana kandungan kadar air, protein dan
karbohidrat yang terbaik adalah pada
perlakuan penambahan jahe $18 \%$. Dimana
nilai rata-rata kandungan kadar air 3,50 ,
kandungan protein 2,17 sedangkan
kandungan karbohidrat 95.61 dan hasil uji
organoleptik penerimaan panelis terhadap
minuman sari biji nangka yang terbaik pada
perlakuan penambahan jahe $18 \%$.

\section{DAFTAR PUSTAKA}

Ditjen POM, Depkes RI. 2000. Parameter

Standar Umum Ekstrak Tumbuhan

Obat. Departemen Kesehatan
Republik Indonesia, Jakarta, 911,16 .

Ernasari., Patang, dan Kadirman. 2018. Pemanfaatan Sari Tebu (Saccharum oficinarum) Dan Lama Fermentasi Kacang Tunggak Terhadap Kualitas Kecap Manis Kacang Tunggak (Vigna unguiculata). JurnalPendidikan Teknologi Pertanian, Vol. 4 (2018) : $88-100$

Fatriani dan Nurul Hikmah. 2007. Rendemen Dan Kualitas Minyak Atsiri Jahe (Zingiber Officinale Rose). Jurnal Hutan Tropis Borneo Volume 08 .

Febriyanti, Nurul., Muhammad Wiharto, dan Lahming. 2018. Pengaruh Lama Pengeringan Dan Berbagai Jenis Gula Terhadap Kualitas Manisan Tomat (Lycopersium esculentum). Jurnal Pendidikan Teknologi Pertanian, Vol. 4 (2018) : 86-94.

Keita, S.M, C. Vincent, J.P. Schmit, S. Ramaswamy, dan A. Belanger. 2000. Effect of various volatile oils on Callosobruchus maculatus ( $F$.) (Coleoptera: Bruchidae). Journal of Stored Product Research 36: 355364.

Kusumaningati, R.W. 2009. Analisa Kandungan Venol Total Jahe (Zingiber officinale Rosc.) Secara Invitro. Jakarta: Fakultas Kedokteran UI .

Lata K., S. Mande S, dan V.V.N. Kishore. 2000. Studies on Quality Improvement of Large-Cardamom using an Advanced Gasifier based 
Dryer. New Delhi: Tata Energy Research Institute.

Lentera. 2002. Khasiat dan Manfaat Jahe Merah Si Rimpang Ajaib. Jakarta: Agromedia Pustaka.

Rusdi, Alhim., M. Wijaya dan Kadirman. 2016. Pembuatan Sari Biji Durian (Durio Zibethinus) dengan Penambahan Ekstrak Jahe Merah (Zingiber Officinale Rosc.).JurnalPendidikan Teknologi Pertanian, Vol. 3 (2017) : S1-S9.

Sari, K.P., Jamaluddin, dan A.Sukainah. 2016. Fortifikasi tempe berbahan dasar kedelai dan biji nangka. JurnalPendidikan Teknologi Pertanian, Vol. 2 (2016) : 16-26

Soepardi.2001. Kajian Karakteristik Jahe Berdasarkan Ukuran dan Lama Perendaman Serbuk Jahe dalam Etanol.Skripsi . Surakarta: Jurusan Teknologi Hasil Pertanian.

Sugito dan Ari Hayati.2006. Penambahan Daging Ikan Gabus (Ophicepallus Strianus Blkr) Dan Aplikasi Pembekuan Pada Pembuatan Pempek Gluten.Jurnal.Volume 8, No. 2.Palembang : Fakultas Pertanian, Universitas Sriwijaya.

Sumardana, Gede., H. Syam dan A.Sukainah. 2017. Subtitusi Tepung Bonggol Pisang pada Mie Basah dengan Penambahan Kulit Buah Naga (Hylocereus undatus).Jurnal Pendidikan Teknologi Pertanian, Vol. 3 (2017) : S145-S157.

Wahyuni, N. 2005.Karakteristik Kimia dan Organoleptik Minuman Instan Madu Bubuk dengan Penambahan
Tepung Kerabang Telur Sebagai Sumber Kalsium.Skripsi IPB, Bogor.

Widiyanti, A. 2009.Analisis Kandungan Jahe (Zingiber officinale rosc.). Skripsi tidak diterbitkan. Jakarta: Fakultas Kedokteran Universitas Indonesia.

Widyastuti, Y.E. 1993. Nangka dan Cempedak Ragam Jenis dan Pembudidayaan.Jakarta: Penebar Swadaya.

Winarno, F.G. 2002.Kimia Pangan dan Gizi.Jakarta: Gramedia Pustaka Utama. 